\title{
SEMIOTIKA LAKON WAYANG BEBER REMENG MANGUNJAYA
}

\author{
Elyandra Widharta \\ Pengkajian Seni - Program Pascasarajana ISI Yogyakarta \\ widhartaelyandra@gmail.com
}

\begin{abstract}
Abstrak: Penelitian ini hendak menjelaskan tentang identifikasi dan karakteristik secara khusus di Gelaran Gunungkidul yang populer dengan nama Remeng Mangunjaya. Adapun tujuan dari penelitian ini adalah untuk menjelaskan teks lakon Wayang Beber Remeng Mangunjaya yang memiliki karakteristik struktur lakon dengan pendekatan semiotika. Dengan analisis melalui pendekatan semiotika lakon, terbukti bahwa secara karakteristik lakon Wayang Beber Remeng Mangunjaya memiliki keunikan sendiri dari teks lakon yang diceritakan. Metode yang digunakan dalam penelitian ini adalah metode analisis data kualitatif. Analisis menggunakan metode reduksi data dan sajian data, sehingga diperoleh kesimpulan mengenai semiotika teks lakon Wayang Beber Remeng Mangunajaya.
\end{abstract}

Kata kunci: wayang, beber, remeng, mangunjaya, semiotika, lakon

\begin{abstract}
This study intends to explain the identification and specific characteristics of the Gelaran Gunungkidul which is popularly known as Remeng Mangunjaya. The purpose of this study is to explain the text of the Wayang Beber Remeng Mangunjaya play which has the characteristics of the semiotic approach structure. By analyzing the semiotic approach of the play, it is proven that characteristically the text of the Wayang Beber Remeng Mangunjaya has its own uniqueness. The method used in this research is qualitative data analysis. The analysis used the data reduction method and data presentation, in order to obtain conclusions about the semiotics of the Wayang Beber Remeng Mangunajaya play text.
\end{abstract}

Keyword: wayang puppet, beber, remeng, mangunjaya, semiotics, play script

\section{Pendahuluan}

Salah satu dampak dari kemajuan teknologi dewasa ini adalah semakin meredupnya seni pertunjukan tradisi. Apakah seni pertunjukan tradisi masih memiliki eksistensi khususnya di era millenial ini. Atau justru lambat laun akan ditinggalkan penontonnya. Dalam hal ini, seni pertunjukan wayang pada umumnya, yang merupakah salah satu kekayaan budaya di Indonesia khususnya di Jawa Tengah atau Yogyakarta. Wayang merupakan salah satu seni pertunjukan tradisi yang berasal dari kebudayaan asli Indonesia. Kesenian wayang telah diakui sebagai karya Adi Luhung oleh UNESCO pada tanggal 7 Nopember 2003 atau Masterpiece of Oral and Intagible Heritage of Humanity (Kominfo, 2011). Wayang sebagai mana dikenal orang dewasa ini merupakan warisan budaya nenek moyang telah amat tua yang diperkirakan telah bereksistensi kurang lebih 3.500 tahun yang lalu (Mulyono, 1989a, p. 1).

Wayang memiliki sejarah yang panjang dari generasi ke generasi di Indonesia khususnya di Jawa. Bahkan sampai dengan detik ini masih saja ada yang menggemari pertunjukan wayang secara terbatas namun ada pula yang mulai 
meninggalkannya. Padahal di tahun 1980an pertunjukan wayang kulit digemari oleh masyarakat karena sarat dengan nilai tuntunan. Jenis wayang yang populer selama ini dikenal yaitu wayang kulit. Meskipun jenis wayang lainya cukup banyak dikenali melalui jenis dan klasifikasinya. Menurut Haryanto (1998), wayang dibedakan menjadi 8 jenis klasifikasi antara lain: wayang madya, wayang topeng, wayang nemak, wayang modern, wayang babad, wayang menak, wayang gedog, dan wayang Beber. Kedelapan jenis wayang tersebut yang memiliki ciri keunikan tersendiri yaitu Wayang Beber.

Nama Wayang Beber berasal dari cara memainkannya, karena pertunjukannya berupa membeberkan cerita dengan membentangkan layar dari kertas yang terdapat gambar-gambar wayang. Wayang Beber dipertunjukkan dengan dalang yang menceritakan lakon sesuai dengan adegan yang tertera di dalam gambar. Wayang Beber saat ini terdapat di dua tempat yaitu Desa Karang Talun, Kelurahan Kedompol, Kecamatan Donorojo Pacitan Jawa Timur. Sedangkan yang satunya ada di Desa Gelaran, Kelurahan Bejiharjo, Kecamatan Karangmojo, Gunungkidul Yogyakarta. Bahkan menurut sebuah survey menyatakan sampai dengan tahun 1980an hanya ada dua tempat penyimpanan Wayang Beber yaitu di Gunungkidul Yogyakarta dan di Pacitan Jawa Timur (Sumanto, 2011).

Wayang Beber keberadaannya saat ini masih disakralkan bahkan dianggap keramat bagi sebagian orang di sekitar desa Gelaran Bejiharjo. Hal itu dibuktikan dengan setiap adanya pertunjukan Wayang Beber harus dilengkapi dengan berbagai sesaji. Salah satu contoh bentuk kesakralan tersebut yaitu Wayang Beber hanya dibuka pada hari Jumat Legi. Wayang Beber Remen Mangunjaya dibuat dari kertas yang berasal dari kulit pohon melinjo. Berbentuk segi empat persegi panjang dan setiap ujungnya diberi semacam kayu pegangan atau disebut seligi.

Wayang Beber terdiri atas 4 gulungan

dengan lakon Remeng Mangunjaya sementara 2 gulungan diperkirakan melakonkan Jaka Tarup. Selain itu, terdapat 2 gulungan lagi yang tidak diketahui ceritanya. Delapan gulungan Wayang Beber tersebut dimiliki keluarga Sapar Kromosentono (Soelarto, 1984). Wayang Beber Remeng Mangunjaya yang populer di Gelaran Gunungkidul Yogyakarta memiliki 4 gulungan yang setiap gulungan menggambarkan 1 babak. Sedangkan dalam 1 babak terdiri dari 4 adegan. Total keseluruhan Wayang Beber Remeng Mangunjaya terdapat 16 adegan. Hal tersebut yang menarik penulis untuk meniliti karakteristik struktut lakon dari Wayang Beber Remeng Mangunjaya.

\section{Penelitian Sebelumnya}

Menurut penilitian sebelumnya deskripsi mengenai pembagian plot adegan Wayang Beber Remeng Mangunjaya (Sahtila, 2008) adalah sebagai berikut:

\section{Babak I}

Adegan I Jenggala: Tatkala Raden Panji Asmarabangun dan Dewi Galuh Candra Kirana masih pengantin baru, pasangan tersebut berbincang-bincang untuk mengetahui seberapa jauh ukuran cinta masing-masing. Galuh menjawab bahwa cintanya kepada Panji adalah seujung kuku. Hal ini membuat Panji malu terutama setelah tahu artinya yakni cinta yang tidak berkesudahan. Panji pun memutuskan untuk mengasingkan diri di Gunung Penanggungan dan menyamar sebagai $\mathrm{Ki}$ Remeng Mangunjaya. Galuh yang marah karena ditinggal Panji akhirnya mengadakan sayembara meniti rotan di atas jurang.

Adegan II: Raja Klana dari kerajaan Bantarangin tertarik untuk mengikuti sayembara yang diselenggarakan oleh Galuh. 
Oleh karena itu, ia mengutus Resi Puyangaking dan Patih Gajah Gurito, dua punggawanya, untuk mengepung Kediri.

Adegan III: Batara Naradha menemui Panji yang sudah menguasai filsafat dan memintanya untuk segera kembali ke Kediri.

Adegan IV: Panji kembali ke Kediri.

\section{Babak II}

Adegan I: Sayembara Nguwot Kayu Penjalin Panji berhasil memenangkan sayembara yang diadakan oleh Galuh.

Adegan II: Panji dan Galuh bersatu kembali.

Adegan III: Galuh menerima kedatangan Ragil Kuning, adiknya.

Adegan IV: Panji menemui Dewi Kilisuci. Di akhir pertemuan, Kilisuci berpesan supaya Panji senantiasa hati-hati di jalan karena Prabu Klana masih akan mengancam.

\section{Babak III}

Adegan I: Sayembara Nguwot Kayu Penjalin. Dalam perjalanan pulang, Panji dihadang oleh Resi Puyangaking.

Adegan II: Panji dan Resi Puyangaking bertempur hebat

Adegan III: Panji yang lebih sakti berhasil mengalahkan Puyangaking

Adegan IV: Panji mengutus dua punggawanya untuk menemui Dewi Kilisuci sementara ia cepat-cepat menuju Kediri karena keraton telah dikepung musuh.

\section{Babak IV}

Adegan I Keraton Bantarangin: Prabu Klana mengutus Patih Gajah Gurito untuk merebut Galuh Candrakirana dari Panji.

Adegan II Keraton Kediri: Prabu Klana menantang Panji dan saudara-saudaranya untuk perang tanding dengannya.

Adegan III Alun-alun Kediri: Panji berperang dengan Patih Gajah Gurito yang memiliki ajian wewe putih. Peperangan yang disaksikan oleh dewa-dewi tersebut dimenangkan oleh Panji.

Adegan IV: Kediri kembali pulih seperti sedia kala dan Panji dapat bersatu kembali dengan Galuh.

Adapun urutan adegan jika digambarkan dalam bentuk alur atau plot adalah sebagai berikut:

Babak I: Adegan IV - Adegan III - Adegan II - Adegan I

Babak II: Adegan IV - Adegan III - Adegan II -Adegan I

Babak III: Adegan I - Adegan II - Adegan III - Adegan IV

Babak IV: Adegan I - Adegan II - Adegan III - Adegan IV

\section{Landasan Teori}

Definisi lakon adalah kisah yang didramatisasi dan ditulis untuk dipertunjukan di atas pentas oleh sejumlah pemain. Lakon merupakan padanan kata untuk drama. Sedangkan definis lakon (play; piece de theatre Pr), Karangan berbentuk drama yang ditulis dengan maksud untuk dipentaskan. Lakon merupakan istilah lain dari drama (Satoto, 2012).

Setiap pertunjukan teater baik modern maupun tradisi memiliki potensi untuk dianalisis dengan pendekatan semiotika. Wayang Beber dalam hal inti tentu saja masuk dalam klasifikasi teater tradisional. Bahwa dalam prespektif semiotika teater, teater sebagai objek kajian bisa dilakukan dengan pendekatan semiotika terhadap teks drama. Semiotika teks drama mendasarkan analisisnya pada tiga unsur, yaitu konstruksi plot, karakter atau tokoh, dan dialog (Nur Sahid, 2019).

Pertunjukan wayang tidak lepas dari sebuah teks cerita atau lakon yang diceritakan oleh seorang dalang. Setiap teks cerita atau lakon wayang memiliki kesamaan dengan karya fiksi, yaitu memiliki struktur lakon yang dapat dianalisis secara intrinsik 
maupun ekstrisik. Bahwa teks cerita wayang terbangun dari unsur intrinsik dan ekstrinsik walau untuk keperluan analisis unsur intrinsiklah yang harus mendapat penekanan. Sementara unsur yang lainya yaitu bentuk dan isi. Penjelasan mengenai unsur bentuk yaitu antara lain alur, latar, bahasa, karakter, tokoh. Sedangkan unsur isi berupa cerita wayang itu sendiri yang terdiri dari peristiwa, konflik, klimaks, pesan dan berbagai unsur yang dipertimbangkan (Burhan, 2006).

Adegan di dalam lakon merupakan hubungan unsur-unsur yang tersusun ke dalam satu kesatuan. Tegasnya struktur lakon adalah tempat hubungan dan fungsi dari adegan-adegan di dalam peristiwa-peristiwa dan di dalam satu keseluruhan lakon. Jadi, jika kita hendak mengkaji sebuah struktur (naskah) lakon, kita harus memulai dengan unit dasar dari bangunan lakon yaitu adegan. (Satoto, 2012).

Melalui deskripsi adegan yang didapat dari data jurnal penelitian sebelumnya sebagai kajian pustaka, didapatkan data bahwa Wayang Beber memiliki struktur lakon antara lain: karakter tokoh, plot atau alur cerita, dan latar kejadian peristiwa. Meskipun tidak terdapat dialog secara baku.

\section{Metode dan Data}

Penelitian ini menggunakan analisis data kualitatif. Pengumpulan data dilakukan dengan cara melalui tahapan dengan 3 komponen. Proses analisis menggunakan tiga komponen utama yaitu: (1) reduksi data, (2) sajian data, dan (3) penarikan kesimpulan serta verifikasinya (Sutopo, 2002). Tahap pertama, reduksi data yaitu proses merangkum, memilih hal yang pokok, dan memfokuskan pada rumusan masalah yang terkait secara spesifik mengenai lakon Wayang Beber Remeng Mangunjaya. Tahap kedua, penyajian data. Data yang sudah berhasil direduksi selanjutnya disajikan dalam bentuk uraian deskripsi untuk memudahkan fenomena yang disampaikan dan merencanakan proses selanjutnya. Tahap ketiga, kesimpulan diperoleh ketika seluruh tafsir analisa secara deskripsi sudah didapat dari hasil reduksi dan pemaparan data. Analisis data dilakukan secara kualitatif untuk mendapatkan data primer dan data sekunder dengan cara deskriptif kualitatif dengan cara membandingkan dan mengamati.

\section{Hasil dan Pembahasan}

Wayang Beber berbentuk gambargambar yang tertulis pada daun siwalan atau rontal (Lontar dari bahasa Jawa: ron tal, "daun tal"). Narasi cerita dalam gambar wayang dilukis kan pada helaian rontal. Garis dan lukisan yang pada daun ini memang sukar hilang. Asal-usul Wayang Beber dimulai sejak zaman kerajaan Jenggala pada 1223 M. Namun pada perkembangan berikutnya ketika Raja Prabu Suryahamiluhur menjadi Jenggala yang kemudian pemindahan kekuasaan keraton ke Pajajaran, cerita wayang purwa yang dikembangkan dalam Wayang Beber. Di sinilah mulanya pemakaian kertas untuk Wayang Beber pada tahun 1244 M. Kertas yang berwarna kekuningan dan disebut dlancang gedhog. Gambar yang mulanya hanya lebih kecil kemudian dibuat lebih besar dan dilengkapi dengan ornamen meskipun masih menggunakan warna hitam putih (Bagyo Suharyono, 2005).

Pada saat pemerintahan Amangkurat II Kerajaan Kartasura tahun 1690 M, gambar Wayang Beber diciptakan kembali dengan lakon Joko Kembang Kuning yang dikerjakan selelai pada tahun $1692 \mathrm{M}$. Perkembangan selanjutnya, pada masa Raja Pakubuwana II di Kartasura dibuat pula Wayang Beber dengan lakon siklus panji Joko Kembang Kuning dan Remeng Mangunjaya yang diselesaikan pada tahun 1735 M. Sampai pada pemberontakan Cina terjadi dan keraton di Kartasura dikuasai oleh 
musuh. Banyak kekayaan atau aset keraton yang kemudian dievakuasi untuk diselamatkan. Beberapa anggota kerajaan membawa semua benda-benda pusaka milik keraton salah satunya termasuk perlengkapan Wayang Beber Joko Kembang Kuning. Sebagian Wayang Beber ini kemudian dilarikan di sekitar Gunungkidul Yogyakarta dan sebagian lagi dilarikan ke Karangtalun Pacitan Jawa Timur. Wayang Beber yang di Pacitan sampai dengan saat ini merupakan wayang yang diwariskan secara turun temurun dari dalang pertamanya $\mathrm{Ki}$ Nolodermo yang berasal dari Dusun Gompol Kecamatan Donorojo Karantalun Pacitan.

Wayang Beber Remeng Mangunjaya saat ini milik keluarga Ki Gunakarya dari Gelaran Bejiharjo Karangmojo Gunungkidul DIY. Wayang Beber ini populer dengan sebutan Wayang Beber Wonosari. Perbedaan paling mencolok dari Wayang Beber Pacitan dan Wayang Beber Wonosari yaitu posisi dalang-nya. Jika versi Pacitan posisi dalang berada di belakang Wayang Beber sedangkan di Wonosari posisi dalang di depan Wayang Beber. Secara karakteristik tidak merubah suatu esensi apapun dalam Wayang Beber justru perbedaan inilah menjadi ciri khas masing-masing daerah dalam upaya pelestariannya.

\section{Karakter Tokoh}

Karakter merupakan tokoh yang menggerakan jalanya sebuah cerita. Cerita tanpa tokoh tentu saja mustahil terjadi sebuah peristiwa. Dalam semiotika karakter yang dikembangkan oleh Ubersfeld mecakup karakter sebagai leksem, karakter sebagai ensambel semiotika dan karakter sebagai wacana. Tokoh atau karakter sebagai leksem memiliki jenis antara lain aktan, metonimi, metafora, referen, konotasi (Sahid 2019). Sementara pengategorian perwatakan tokoh cerita ke dalam watak sederhana dan bulat (kompleks), pada dasarnya karakter tokohtokoh wayang yang bersifat sederhana, walaupun dalam lakon-lakon tertentu ada tokoh yang tidak terlalu sederhana dan cenderung ke karakter yang kompleks (Burhan, 2006).

Dalam pembagian tokoh terdapat empat jenis yang merupakan anasir dari sisi kejiwaan. Protagonis ialah tokoh utama, merupakan pusat sentral cerita. Antagonis adalah tokoh lawan atau musuh yang menimbulkan konflik. Tritagonis adalah tokoh penengah bertugas menjadi pelerai atau pendamai. Peran pembantu adalah perang yang secara tidak langsung terlibat dalam konflik yang terjadi tetapi ia diperlukan untuk membantuk menyelesaikan cerita (Satoto, 2012).

Karakter atau tokoh yang terdapat dalam lakon Wayang Beber Remeng Mangunjaya yaitu Raden Panji Asmarabangun, Dewi Galuh Candra Kirana, Raja Klana, Resi Puyangaking Patih Gajah Gurito, Batara Naradha, Ragil Kuning, dan Dewi Kilisuci

1.1. Raden Panji Asmarabangun: tokoh protagonis laki-laki dalam lakon Wayang Beber. Ia yang menyamar menjadi Ki Remeng Mangunjaya saat mengasingkan diri di Gunung Penanggungan.

1.2. Dewi Galuh Candra Kirana: tokoh protagonis perempuan yang merupakan istri atau pasangan dari Raden Panji Asmarabangun.

1.3. Raja Klana: tokoh antagonis laki-laki dari Ia berasal dari Kerajaan Bantarangin yang merupakan musuh dari Raden Panji Asamarabangun. Memiliki kedudukan sebagai tokoh mendukung cerita bahkan konflik.

1.4. Resi Puyangaking: tokoh atau peran pembantu laki-laki yang merupakan punggawa utusan dari Raja Klana dari Kerajaan Bantarangin.

1.5. Patih Gajah Gurito: tokoh atau peran pembantu laki-laki yang merupakan 
punggawa utusan dari Raja Klana dari Kerajaan Bantarangin.

1.6. Batara Naradha: tokoh tritagonis dalm wujud dewa laki-laki yang bijaksana dimana ia yang menasehati Panji untuk segera kembali ke Kediri setelah menguasai filsafat.

1.7. Ragil Kuning: tokoh atau peran pembantu perempuan yang merupakan adik dari Dewi Galuh Candra Kirana.

1.8. Dewi Kilisuci: tokoh tritagonis dalam wujud dewi perempuan yang merupakan penasehat Raden Panji Asmarabangun.

Dalam semiotika karakter sebagi leksem yang masuk dalam jenis aktan yaitu Raden Panji Asmarabangun dan Dewi Galuh Candra Kirana merupakan karakter yang memiliki fungsi gramatikal. Keduanya menjadi subjek cerita yang memiliki kekuatan karakter masing-masing dalam setiap adegan maupun babak. Sedangkan Batara Naradha dan Dewi Kilisuci termasuk jenis metafora yaitu penggambaran sosok spiritual atau dewa dewi yang memberikan nasehat serta petuah bijak.

\section{Plot}

Plot adalah alur, rangka, cerita, merupakan susunan empat bagian yaitu prostasis, epitasio, catastasis, catastrophe. Dalam pengertian lain bisa dipahami sebagai pokok persoalan: konflik - krisis - klimaks penyelesaian (Harymawan, 1986). Plot adalah lakon atau kisahan, yang mengulur drama. Plot yang bagus adalah selalu "menunda" kejadian sampai akhir drama (Suwardi, 2014). Umum dipahami tahapan dalam laku dramatik lakon terdiri dari 5 bagian yaitu; eksposisi, penanjakan (rising action), klimaks, penurunan (falling action), dan kesimpulan (denoument). Tahapan klasik ini kemudian lebih diperinci menjadi 7 bagian sehingga dramatika lakon lebih mudah diurai. Secara berurutan 7 bagian tersebut adalah eksposisi, konflik awal, penanjakan, klimaks, penurunan, resolusi, dan kesimpulan (Harymawan, 1986).

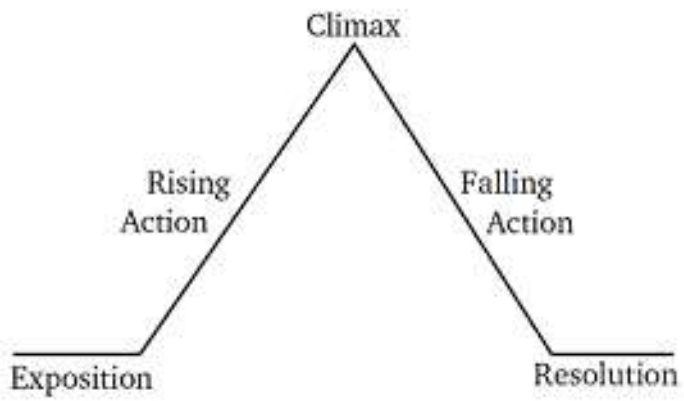

The Freytag Triangle

\section{Gambar 1. Plot dramatik versi Gustav \\ Freytag}

Wayang beber Remeng Mangunjaya memiliki plot yang linier setiap babaknya. Alur linier yaitu alur yang lurus (Satoto, 2012). Meskipun di babak yang lain terdapat adegan yang bermula dari adegan 4 ke adegan 1 atau sebaliknya. Dalam hal ini pengertian linier yaitu plot yang lurus dengan dimulai dari pokok persoalan yaitu konflik krisis - klimaks - penyelesaian.

Tahap konflik utama tentu saja dimulai pada Raden Panji Asmarabangun pergi mengasingkan diri ke Gunung Penganggungan dan menyamar sebagai $\mathrm{Ki}$ Remeng Mangunjaya. Karena malu cintanya oleh Dewi Galuh Candra Kirana dianggap hanya seujung kuku. Dewi Galuh Candra Kirana yang marah akhirnya mengadakan sayembara.

Tahap krisis mulai nampak menonjol ketika Dewi Galuh Candra Kirana mengadakan sayembara meniti rotan di atas jurang. Sampai pada adegan dimana Raja Klana dari kerajaan Bantarangin tertarik untuk mengikuti sayembara yang diselenggarakan oleh Galuh. Krisis semakin memanas ketika Raja Klana memerintahkan 
punggawanya Resi Puyangaking dan Patih Gajah Gurito, untuk mengepung Kediri.

Tahap klimaks ditunjukan pada adegan dimana Raden Panji Asmarabangun berperang melawan Raja Klana. Dimana Keraton Kediri juga sudah dikepung. Raden Panji berhasil mengalahkan Resi Puyangaking dan Patih Gajah Gurito yang memiliki ajian wewe putih. Sampai akhirnya Raden Panji Asmarabangun juga berhasil mengalahkan Raja Klana.

Tahap penyelesaian terjadi saat Keraton Kediri kembali pulih sedia kala dimana Raden Panji Asmarabangun dan Dewi Galuh Candra Kirana bersatu kembali.

\section{Latar}

Latar dalam arti yang lengkap meliputi aspek ruang dan waktu terjadinya peristiwa. Bagian dari teks dan hubungan yang mendasari suatu laku (action) terhadap keadaan sekeliling. Perumusannya, latar dipandang sebagai bagian dari jenis informasi (disamping background atau latar belakang, evaluation atau penilaian, dan collateral atau yang mengiring/yang terjadi bersamaan); dimana atau where, kapan dan saat atau waktu dalam masalah apa kejadian itu ditempatkan. Dalam konteks ini, latar dibicarakan dalam non events. (Satoto, 2012).

Lakon Wayang Beber Remeng Mangunjaya memang hanya disebutkan dalam deskripsi babak dan setiap adegan yaitu empat tempat kejadian peristiwa itu berlangsung sebagai sebuah cerita. Ketiga tempat tersebut antara lain: Gunung Penanggungan, Keraton Kediri, Alun-alun Kediri, dan Kerajaan Bantarangin.

\section{Simpulan}

Wayang Beber merupakan salah satu seni teater tradisional yang sudah berkembang sejak abad ke 12 di Indonesia saat peradaban kebudayaan Hindu-Budha. Wayang Beber mengalami perubahan pada bentuk mulai dari gambar yang dilukiskan khususnya Wayang Remeng Mangunjaya ini terdapat di Dusun Gelaran Bejiharjo, Karangmojo, Gunungkidul DIY. Penamaan populer dengan sebuatn Remeng Mangunjaya karena terdapat pada jalinan cerita lakon yang menyebutkan bahwa Raden Panji Asmarabangun saat mengasingkan diri di Gunung Penanggungan menyamar dengan nama Remeng Mangunjaya.

Sebagai pendekatan semiotika lakon, rupanya Wayang Beber Remeng Mangunjaya memiliki struktur lakon yang cukup lengkap untuk diuraikan. Hal tersebut nampak pada penokohan dari masing-masing adegan dan setiap babaknya. Meliputi juga bagian alur atau plot cerita yang linier atau memiliki konstruksi plot yang garis lurus yaitu konflik - krisis - klimaks penyelesaian.Selain itu, lakon Wayang Beber Remeng Mangunjaya terdapat tokoh atau karakter yang beragam karena nampak dalam lakon tersebut terdapat jenis tokoh protagonis, antagonis, tritagonis dan tokoh atau peran pembantu. Sedangkan pada bagian latar deskripsi adegan lakon tersebut terjadi di empat tempat kejadian yaitu Gunung Penanggungan, Keraton Kediri, Alun-alun Kediri dan Kerajaan Bantarangin.

Dalam deskripsi lakon memang tidak terdapat dialog yang baku seperti sebuah naskah yang utuh. Jadi, hal ini juga membuat kendala atau kesulitan peniliti untuk meniliti lebih jauh mengenai penekanan karakter atau penokohan yang bisa dianalisis melalui aspek dialog. Misalnya saja pada saat menganalisa semiotika karakter sebagai ensambel semiotika. Cukup susah dianalisis karena tidak adanya dialog dalam lakon, karena analisis dialog untuk memahami dan mengidentifikasi karakteristik tokoh secara intrinsik maupun ekstrinsik. Padahal pendekatan semiotika dialog bisa membantu peniliti untuk menganalisis melalui sistematika dialog yang digunakan untuk 
menstrukturkan wacana lakon wayang menjadi lebih lengkap.

Cerita lakon dalam Wayang Beber memang tidak lepas dari cerita panji. Pola dan temanya cenderung memiliki kemiripan antara cerita Panji satu dengan yang lain. Hanya yang membedakan lebih ke perkembangan kultural karena letak geografis. Perbedaan yang paling menonjol biasanya nampak pada variasi jalan cerita atau alur/plot. Melalui analisis di atas yang paling menonjol memang pada adegan saat Raden Panji Inukertapati menyamar sebagai seorang pendeta atau pertapa bahkan seorang petualang. Sedangkan penyamaran yang lain pada adegan Dewi Galuh Candrakirana yang menyamar sebagai seorang satria atau perawan desa. Sementara di adegan Prabu atau Raja Klana dengan berbagai macam cara dia menyamar selalu datang dari seberang lautan. Tempat yang dirujuk biasanya yaitu berasal dari Bugis. Namun upaya mempersunting Dewi Galuh Candrakirana selalu mengalami kegagalan.

Ada tafsir lain yang hampir mirip terjadi yaitu dimana lakon pada adegan tersebut menyebutkan Prabu atau Raja Klana mati dalam peperangan dan lari kembali ke seberang lautan. Akhir dari cerita juga selalu ditutup dengan cerita pertemuan kembali antara Raden Panji Asmarabangun dengan Dewi Galuh Candra Kirana dengan suasana yang bahagia (happy ending). Suasana bahagia tersebut menjadi bagian dari upayaupaya kisah Raden Panji Asmarabangun dan Dewi Galuh Candrakirana dalam mengatasi segala macam rintangan untuk menguji iman dan kesetiaan mereka berdua.

\section{Daftar Pustaka}

Bagyo, S. (2005). Wayang Beber Wonosari. Bina Citra Pustaka.

Budiono, H. (2001). Simbolisme dalam Budaya Jawa. Hanindita Graha Widia.
Dirjen Informasi dan Komunikasi Publik. (2011). Wayang Sebagai Media Komunikasi Tradisional dan Diseminasi Informasi. Kementrian Komunikasi dan Informatika RI.

Endraswara, S. (2014). Metode Pembelajaran Drama - Apresiasi, ekspresi dan Pengkajian. PT Buku Seru.

Haryanto, S. (1988). Pratiwimba Adiluhung: Sejarah dan Perkembangan Wayang. Jambatan.

Harymawan, R. M. (1986). Dramaturgi. Rosda Karya.

Mulyono, S. (1989). Simbolisme dan Mistisisme dalam Wayang. Gunungagung.

Nurgiyantoro, B. (1998). Tranformasi Unsur Pewayangan dalam Fiksi Indonesia. Gadjah Mada University Press.

Sahid, N. (2019). Semiotika Teater. Pustaka Pelajar.

Sahtila, L., Sasi, G.A., \& Christian, A.A. (2008). Makna Simbolis dan Nilai Historis Wayang Beber Kyai Remeng. Jurnal Penelitian Universitas Negeri Yogyakarta. https://journal.uny.ac.id/index.php/pe lita/article/view/4357.

Satoto, S. (2012). Analisis Drama dan Teater. Ombak.

Subandi, S., Aswoyo, J., Prabowo, R. A., \& Yuwono, B. T. (2011). Wayang Beber Remeng Mangunjaya Gelaran Wonosari dan Wayang Beber Jaka Kembang Kuning Karangtalun Pacitan Serta Persebarannya di Seputar Surakarta. ISI Press Solo.

Sutopo, H. B. (2002). Metode Penelitian Kualitatif - Dari Teori dan Terapannya dalam Penelitian. Sebelas Maret University Press. 